\title{
Lysinuric Protein Intolerance
}

National Cancer Institute

\section{Source}

National Cancer Institute. Lysinuric Protein Intolerance. NCI Thesaurus. Code C121563.

A disorder caused by the inability to digest and use lysine, arginine, and ornithine. Lysinuric protein intolerance is caused by mutations in the SLC7A7 gene. $y+\mathrm{L}$ amino acid transporter 1, the product of the SLC7A7 gene, is involved in transporting lysine, arginine, and ornithine between cells in the body. 